\title{
THE ROLE OF INTERNATIONAL MONETARY FUND (IMF) IN ECONOMIC RECOVERY DURING ECONOMIC CRISIS OF INDONESIA
}

\author{
Lena Farsia \\ Faculty of Law, Syiah Kuala University, Indonesia \\ Jl. Putroe Phang No. 1 Darussalam, Banda Aceh, 23111 \\ Tel./Fax: +62-651-7552295 e-mail: farsia.lena@unsyiah.ac.id
}

\begin{abstract}
The International Monetary Fund (IMF) has a primary role in providing financial support to countries facing financial crises, such as the 1998 world financial crisis. The situation has brought an enormous impact on developing countries, particularly Indonesia. This paper explores the role of The IMF and maps out the problems related to the financial crisis and its impact on Indonesian political reforms. It will be done by compiling the milestones in chronological order from 1997 until 2017. It also aims to examine the lending policies of the International Monetary Fund, which brings a country like Indonesia becomes addicted and difficult to survive or improve in its economic development. There will be an understanding of how the actual process happens. It can be used as an instrument to assess whether the existence and role of the IMF in Indonesia have a better or harmful impact on the long-term economic development of Indonesia.
\end{abstract}

Keywords: The International Monetary Fund (IMF), Economic Development, Financial Crisis

\section{A. Introduction}

The 1998 world financial crisis brought an enormous impact not only on the developed but also on the third world and developing countries, especially in Asia. Indonesia is one of the countries hit by the crisis, together with other Southeast Asian countries such as Thailand, Malaysia, and Vietnam. However, compared to other southeast Asian countries, Indonesia had the worst impact on it. The financial crisis in Indonesia is more interesting to be examined than others because there is an involvement of the IMF in the economic recovery process. Moreover, the political reformation issues and another financial crisis in 2008 worsened the effort to bring it up from the difficult situation.

The existence and intervention of the IMF in the Indonesian financial crisis has led to a long-term impact on a country that has a solid potential capacity to be a leader in South East Asia due to its population, territory, and especially in human and natural resources. 
This paper examines the role of the IMF in Indonesia. It works out on the matter of financial crisis like the global and regional events and the national crisis, particularly the Indonesian political reforms. It will be done by compiling the milestones in chronological order from 1997 until 2017. It also aims to explore the lending policies of the IMF, which brings a country like Indonesia becomes addicted and difficult to survive or improve in its economic development.

\section{B. Research Method}

This research used the noramtive research method, which is defined as any research where conclusions of the study are strictly drawn from legislation and the likes. Qualitative research is mainly used for gathering non-numerical data. It is used to find meanings, opinions, or underlying reasons from its subjects. These methods are unstructured or semi-structured.

\section{Findings and Discussion}

\section{a. The role of International Monetary Fund and Policies}

The International Monetary Fund (hereinafter IMF) is one of the institutions which provides financial assistance to countries which face financial crisis. The IMF was established with the International Bank for Reconstruction and Development (now commonly known as the World Bank) signed in Bretton Woods Agreements. The establishment of the IMF has little to do with the economic programs in developing countries that the IMF is famous for today ${ }^{1}$.

Article I of the Articles of Agreement of the IMF sets out its purposes: to create a permanent institution for consultation on international monetary problems; to promote the growth of international trade, and thereby full employment and economic growth; to promote exchange stability and avoid competitive devaluations; to promote current account convertibility; and to lend under adequate safeguards to member countries, to enable them to adjust the balance of payments difficulties "without resorting to measures destructive of national or international prosperity." ${ }^{2}$

\footnotetext{
${ }^{1}$ Vreeland, James Raymond, the International Monetary Fund, Routledge Global Institutions, New York, 2006 at. 5

${ }^{2}$ Fischer Stanley, IMF Essays from a Time of Crisis: The International Financial System, Stabilization and Development, the MIT Press, Cambridge, Massachusetts, London, England, 2004, at. 99.
} 
Naturally, the IMF was designed to monitor and help adjustable exchange rates globally, considering the currencies of different countries are convertible into gold. Therefore countries would make the payment using the gold due to the standard of balance. However, "if countries faced a balance of payments deficit, for example, the value of its imports exceeded the value of its exports; therefore, the requirement to back up the domestic currency by gold would force the supply of money down. As a result, demand for the imported goods would go down (because their prices would be too high), and the balance would right itself"3.

\section{The Role of the IMF}

The IMF is one of the most effective mechanisms through which the international community promotes good macroeconomic and financial sector policies among its members. ${ }^{4}$ There are some reasons to support this mechanism; first, there is regular surveillance of economic policies and prospects. The supervision of financial and opportunity can be formed as a report and spread as a publication to other members. This publication would contribute to domestic policy debate and provide information to actual and potential investors. The growing transparency of the IMF is desirable in its own right; it is an essential means to increase the IMF's effectiveness. ${ }^{5}$ In addition, surveillance also has a regional dimension. It triggers the other countries to establish the same report in economic transparency. Surveillance can help to prevent financial problems from escalating into crises.

Under Article IV of the IMF's Articles of Agreement, member countries undertake to collaborate with the IMF and promote the stability of the global system of exchange rates. In particular, they commit to running their domestic and external economic policies in keeping with a mutually agreed code of conduct. For its part, the IMF is charged with (i) overseeing the international monetary system to ensure its effective operation and (ii) monitor each member's compliance with its policy obligations. To ensure that surveillance remains effective, the IMF is constantly reviewing its policy framework. ${ }^{6}$

\footnotetext{
${ }^{3}$ Vreeland, id, at 6

${ }^{4}$ Fischer, id, at .100

${ }^{5}$ Ibid

${ }^{6}$ Wang Jiangyu, 2011, Lecture material : International Financial Regulation, Part II: IMF, Financial Liberalization, and Financial Crises.
} 
Second, the IMF provides technical assistance to governments and central banks. It helps countries to develop and maintain an adequate policy-making capacity. ${ }^{7}$ For instance, by setting up modern statistical systems in the transition economies with exceptional data, IMF helped industrialized and emerging market countries to upgrade the quality. Another example is when the IMF helped the authorities of Brazil to develop and implement a good inflation targeting regime. In this area, the IMF tried to have a good relationship with the central bank of Brazil to exchange some ideas and make it work better. ${ }^{8}$ Both of the two mechanisms of the IMF make a valuable contribution to the world economy. However, outside of the policy-making, these mechanisms are not recognized.

There are three categories of countries that will be given the loan from the IMF:

(1) The poorest countries.

The IMF lends to the poorest countries on concessional terms, originally under the enhanced structural adjustment facility (ESAF) and now under the Poverty Reduction and Growth Facility (PRGF). In this program, the IMF and the World Bank enhanced the debt reduction scheme for the poorest countries by enacting anti-poverty measures. PRGF provides a framework to ensure macroeconomic stability and medium-term viability. This framework is needed for two reasons. First, macroeconomic stability is essential to prolonging growth and maintain resources. As we know, most impoverished countries usually do not have many resources; therefore, they must use the resources efficiently. Second, since the world community provides a massive amount of assistance to these countries, the creditor countries need to ensure the loan or grant assistance. Therefore they need the assurance to make sure that the aid is using to stabilize the macroeconomic environment. Thus IMF will guarantee the creditor countries. ${ }^{9}$

(2) The post-communist transition economies

The IMF helped the countries in the post-communist transition like the Soviet Block. Although there was little precedent for an effort of this type, a professional

\footnotetext{
${ }^{7}$ Ibid at 103

${ }^{8}$ Presentation by Stanley Fischer to the International Financial Institution Advisory Commission, February 2, 2000 at https://www.imf.org/en/News/Articles/2015/09/28/04/53/sp020200 access date March 5, 2018

${ }^{9}$ Ibid
} 
consensus developed rapidly. The transition countries needed both macroeconomic stabilization and massive structural reform. These changes involved the growth of essential institutions, including an efficient monetary area and a suitable judicial outline. $^{10}$

The progress of transition countries is varying because it depends on the growth of macroeconomic and the habit of the government to reduce spending money for nothing. The international organizations and individual member governments have sought to support reformist policies as the IMF did in Ukraine and Russia. This idea can help countries develop their institutions, strengthen the legal system, enhance transparency, and fight corruption.

(3) Other countries in difficulty but not in a financial crisis

The IMF lends to countries, not in crisis but experiencing significant economic difficulties. In this area, the IMF provides an external restriction on the policy applicable to local policymakers in implementing necessary but often painful reforms. The IMF's involvement instills confidence in residents and foreign investors to implement the policy framework. In more technical language, such programs serve as both commitment and signaling devices. ${ }^{11}$

It is possible for IMF to lend some money to these countries because the IMF provides a mechanism which ensures the policy commitments will be monitored and reviewed, in the first instance by the staff and then by the Board of the IMF, representing the international community. For example, the IMF programs that support Turkey and Colombia. Here, the IMF provides financial support to countries that have shown themselves prepared to implement sound policies. Sometimes countries find that an IMF - supported program provides the framework for a coherent attack on a long-standing problem that had hitherto appeared intractable. $^{12}$

As mentioned above, the IMF has played an essential role as a financial institution in a financial crisis since its establishment, particularly in developing countries in Asia. 1998 was the peak of the world economic crisis; almost half of the 
Asia continent impacted it. The currency of Asian countries was dropped below the United States Dollar (USD). Asian countries tried to respond to the crisis by utilizing natural resources; however, it would not help much. Some countries thought that one of the solutions to overcome was by getting a loan from the IMF. Asian countries like Thailand, Vietnam, and Indonesia have welcomed the IMF assistance; however, Malaysia rejected it.

The IMF acted in Southeast Asia and Korea in much the same way it did in Eastern Europe and the former Soviet Union: insisting on fundamental changes in economic and institutional structures as a condition for receiving IMF funds. It is doing so even though the situations of the Asian countries are very different from that of the former Soviet Union and Eastern Europe. In addition, the IMF is applying its traditional mix of fiscal policies (higher taxes, less government spending) and credit tightening (implying higher interest rates) that were successful in Latin America. In assessing the appropriateness of these policies, it is necessary to understand what is happening in Asia $^{13}$.

The role of IMF applied in the European countries did not suitable to be used in Asian countries, so the IMF met some difficulties and had to reform its policies. Some difficulties were recognized as: first, the borrowing country could not rely on IMF conditionality because it could not provide the solution on the primary source of balance of payments trouble and its main remedy. Second, disagreements concerning the scope, timing, and policing of the standard fund set of stabilization measures. The IMF is not satisfied only with assurances that its loan will be repaid over the medium term as agreed or that the program the borrower has adopted provides a reasonable promise that such repayment would be feasible. The IMF also has other objectives, resulting in part from articles of agreement and the practices built up during the last 30 years. ${ }^{14}$ The IMF plans to renew its view on stabilization procedures in individual countries within an impressive batch of purposes and restrictions. Refer to what one senior expert on its staff stated that "the ultimate aim of IMF financial assistance is to restore the viability of the balance of payments in a context of price stability and sustained economic growth,

\footnotetext{
${ }^{13}$ Martin Feldstein, Refocusing the IMF, originally Published in Foreign Affairs, in http://www.nber.org/feldstein/fa0398.html, access date March 10, 2018.

${ }^{14}$ Avramovic, Dragoslav,1983, IMF Conditionality : The Role of The International Monetary Fund : Dispute, Qualifications, and Future, edited by John Williamson, Institute for International Economics, Washington DC, pp 595 - 603
} 
without resort to measures that impair the freedom of trade and payments." ${ }^{15}$ Only the countries like Hong Kong, Singapore, and Taiwan can do that at the same time. While some developing countries cannot do this because they have to sacrifice one to get another one, they have to cut the price to expand exports, and some will have to constraint nonessential imports. Third, the IMF adheres to a specific theory of economic policy that is at variance with the views held by a varying number of borrowing countries at any particular time. ${ }^{16}$

Fourth, the IMF gives uncertainties and doubts. "The growing number of developing countries are now using the advisory services of private investment banking houses on debt rescheduling, debt management, and borrowing strategy and tactics, at fees that may exceed \$1 million a year: Turkey, Zaire, Jamaica, Gabon, Costa Rica, Sudan, Uganda, Zimbabwe, Peru, Bolivia, Dominican Republic, Senegal, Ghana, Indonesia, Sri Lanka, Cameroon, among others. This advice, particularly concerning establishing contacts with potential private lenders, can perhaps be provided only by such private banking houses. However, most of the rest should be par excellence the function of international agencies". ${ }^{17}$

Since the financial crisis happened in Asia, the IMF tried to respond to it by providing some programs, especially for Indonesia, which had nine main goals. The goals are to prevent outright default on foreign obligations; to limit the extent of currency depreciation; to preserve a fiscal balance; to limit the rise in inflation; to rebuild foreign exchange reserves; to restructure and reform the banking sector; to remove monopolies and improve the domestic non-financial economy; to preserve confidence and creditworthiness, and to limit the decline of output. ${ }^{18}$

\section{b. Policies of the IMF}

To achieve these objectives, the programs have six key policy components, which are: fiscal policies contraction; bank closure; enforcement of capital adequacy standards to recapitalize the banks; tight domestic credit to defend the exchange rate by raising interest rates; debt repayment backed by bailout funds mobilized by the IMF;

\footnotetext{
${ }^{15}$ Guitian, Manuel, 1981, Conditionality: access to Fund Resources, "Finance and Development".

16 Avramovic, id, at 597

17 Ibid 598

18 Saxena, Sweta Chaman, A country Report on Indonesia, May $8^{\text {th }}, 1998$ at http://citeseerx.ist.psu.edu/viewdoc/download;jsessionid=383453C0F3A4955293762F3070F96E62?doi= 10.1.1.456.8567\&rep=rep1\&type=pdf access date April 5, 2018
} 
and Non-financial structural changes aimed at reducing tariffs, opening sectors for foreign investment and reducing monopoly powers. From those policies, only two of them worked properly during the period.

(a) Fiscal policy contraction;

The program involved fiscal tightening. The extent of the tightening was mild in Indonesia, while it was reasonably strong in Brazil. ${ }^{19}$ The IMF justified the gentle tightening of fiscal policy in Indonesia because countervailing measures were needed to lessen the burden of the private sector in external adjustment and cover the carrying cost of the public debt burden arising from recapitalizing the financial industry. Moreover, fiscal tightening has traditionally served as a signaling device, indicating the government's resolve to take corrective action. ${ }^{20}$

The signaling role was particularly pertinent in Indonesia, where the tightening primarily reflected the elimination or postponement of prestige projects linked to the President's family. The need for a fiscal correction to cover the cost of bank restructuring cannot be disputed because the potential quasi-fiscal costs of the banking crisis were very high. ${ }^{21}$

However, Dr. A.J.W. Van de Gevel said that it is not clear why government budgets were central to the IMF program since the fiscal policy had been reasonably prudent across the region and was not the source of the crisis. The IMF argued that fiscal contraction was necessary to reduce the current account deficit. The budgetary targets were simply added to the contraction. Later, in February 1998, the IMF has rethought its position and allowed Thailand to run a small fiscal deficit. One of the IMFamental difficulties with the IMF packages was that they prescribe tighter budgets and tighter monetary policy aimed at sharply restricting aggregate demand. The objective was to free up resources by squeezing down domestic consumption to devote more output to sales in global markets. ${ }^{22}$

However, this contributed to deflationary pressure on world markets, evoking protests from competitors in G-7 countries that complaint about dumping. The resulting global excess supply in the markets of goods produced in Asia may have

\footnotetext{
${ }^{19} \mathrm{http} / /$ www.imf.org/external/np/ieo/2003/cac/pdf/Ind.pdf access date April 5, 2011, at $11.11 \mathrm{am}$

${ }^{20}$ Ibid

${ }^{21}$ Ibid

${ }^{22}$ Van de Gevel, Diagnosis of Financial Crisis in Asia, Tilburg University, at https://pure.uvt.nl/portal/en/publications/diagnosis-of-financial-crisis-in-asia(04e31e54-c9bc-49c0-a2f4bafa9971f0c2).html access date April 5, 2018
} 
the effect of bringing about a collapsing currency with the attendant rise in the burden of repaying debts in hard foreign currencies. ${ }^{23}$

Therefore, the IMF package may result in a currency collapse because it squeezes domestic demand where excess supply already exists. The only way to increase the global market in the face of the failure of domestic demand is to depreciate sharply. Indeed, after IMF programs were announced in Indonesia and Korea, their currencies dropped more sharply than those of Taiwan and Singapore, where IMF programs were not introduced. ${ }^{24}$

(b) Bank closures;

In Indonesia, a weak banking system significantly contributed to the onset and severity of the crisis. The problem in the banking sector was further compounded by the distress of the highly leveraged corporate industries brought about by sharp currency depreciation and the associated interest rate hikes. ${ }^{25}$

Therefore, many aspects of the crisis in Asia differed from the previous financial crisis in Latin America and the Soviet Union, where the IMF programs were successful.

\section{b. Economic Development Condition and Political Issue}

Before the crisis, the Indonesian economy was characterized by robust economic performance. From 1989 to 1996, annual real Gross Domestic Product growth average 8 percent, led by solid investment behavior. Macroeconomic fundamentals also appeared to be strong. At nearly 10 percent a year, inflation was a little higher than in other East Asian Countries, but it was still low by developing country standards. ${ }^{26}$ The crisis began in July 1997 with contagion from Thailand, which led to pressure on the rupiah. At that time, the central bank, Bank Indonesia (BI), found that the markets widened the intervention margins of the crawling peg regime from 8 percent to 12 percent. ${ }^{27}$ In this condition, Indonesia tried to respond to the crisis by increasing the interest rate on a one-month central bank certificate (SBI) to 30 percent. However, it would not help to recover it. Then in mid-September 1997, Indonesian

\footnotetext{
23 Ibid

${ }^{24}$ Ibid

${ }^{25} \mathrm{http}$ ://www.imf.org/external/np/ieo/2003/cac/pdf/Ind.pdf access date April 5, 2018, at $11.11 \mathrm{am}$

${ }^{26}$ Recovery from the Asian Crisis and the Role of the IMF at

http://www.imf.org/external/np/exr/ib/2000/062300.htm\#box3 access date April 3, 2018

${ }^{27} \mathrm{http}: / /$ www.imf.org/external/np/ieo/2003/cac/pdf/Ind.pdf access date April 5, 2018, at $11.11 \mathrm{am}$
} 
authorities opened discussions with IMF on a precautionary arrangement to restore confidence. $^{28}$

The countermeasures of Indonesian authorities which was restored the economic system during the period 1995 to 2001 can be seen in the table below.

Table 1. Indonesia: Key Economic Indicators1 29

\begin{tabular}{lllllllll}
\hline & 1994 & 1995 & 1996 & 1997 & 1998 & 1999 & 2000 & 2001 \\
\hline Real GDP growth (percent) & 7.5 & 8.2 & 7.8 & 4.7 & -13.1 & 0.8 & 4.9 & 3.4 \\
Real private consumption (percent) & 7.8 & 12.6 & 9.7 & 7.8 & -6.2 & 4.6 & 1.6 & 4.4 \\
Real fixed investment (percent) & 13.8 & 14.0 & 14.5 & 8.6 & -33.0 & -18.2 & 16.7 & 7.7 \\
Real private fixed investment (percent) & 13.8 & 18.9 & 16.6 & 5.4 & -33.0 & -40.3 & $\ldots$ & $\ldots$ \\
Inflation (CPI, Dec./Dec., percent) & 9.6 & 9.0 & 6.0 & 10.3 & 77.6 & 1.9 & 9.3 & 12.5 \\
Base money (end-period, percent) & $22.02,3$ & 34.02, & 13.92 & 68.12 & 32.52 & 35.5 & 22.8 & 2.1 \\
& & 3 & & & & & & \\
Broad money (M2, end-period, percent) & 20.2 & 27.6 & 29.6 & 23.2 & 62.3 & 11.9 & 15.6 & 13.0 \\
Current account balance (US\$, billion) & -2.8 & -6.4 & -7.7 & -4.9 & 4.1 & 5.8 & 8.0 & 6.9 \\
Export growth (US\$, percent) & 8.8 & 13.4 & 9.7 & 7.3 & -8.6 & -0.4 & 27.7 & -16.1 \\
Import growth (US\$, percent) & 12.9 & 27.0 & 5.7 & -2.9 & -34.4 & -12.2 & 39.6 & -7.5 \\
External debt (US\$ billion, end-period) & 100.9 & 113.7 & 121.1 & 146.6 & 159.8 & 158.4 & 149.6 & 139.8 \\
International reserves (US\$ billion, end-period) & 12.1 & 13.7 & 18.3 & 16.6 & 22.7 & 26.4 & 28.5 & 27.2 \\
Exchange rate (Rp/US\$, end-period) & 2,198 & 2,294 & 2,362 & 4,375 & 7,850 & 6,988 & 9,675 & 10,450 \\
Real effective exchange rate4 & 100.2 & 100.0 & 103.9 & 62.1 & 65.8 & 72.7 & 62.9 & 66.3 \\
Central government balance & & & & & & & & -1.1 \\
(percent of GDP)5 & & & & & & & -3.7 \\
\hline
\end{tabular}

Sources: IMF database, supplemented by APD staff estimates; and Datastream.

The shift in financial market sentiment that originated in Thailand exposed structural weaknesses in Indonesia's economy, notably the large amount of short-term foreign debt owed by the private corporate sector. On November 5, 1997, the IMF's Executive Board approved financial support of up to SDR 7.3 billion or about US\$10 billion, equivalent to 490 percent of Indonesia's quota, over the next three years. ${ }^{30}$

The initial program envisages the urgency of dealing with financial sector problems, other trade and agricultural reforms, deregulation, and governance issues that had led to perceptions of an uneven playing field. In October 1997, the IMF negotiated Stand-By Arrangement (SBA) for about US\$ 10 billion, which the Executive Board approved on November 5. ${ }^{31}$ At this stage, the IMF believed that the crisis was a

\footnotetext{
${ }^{28} \mathrm{Ibid}$

${ }^{29}$ The IMF and Recent Capital Account Crises: Indonesia, Korea, Brazil at http://www.ieoimf.org/ieo/files/completedevaluations/07282003main.pdf, access date at March 12, 2018

${ }^{30} \mathrm{Ibid}$

${ }^{31}$ Ibid
} 
moderate case of contagion. The exchange rate had overshot, so the program's critical macroeconomic objective was to correct this overshooting. ${ }^{32}$

In November program purposed to revive market trust by (1) sustaining prudent macroeconomic policies through a combination between fiscal surplus and limit money expansion; (2) stressing fundamental disadvantages in the financial sector, including the closure of 16 banks; (3) undertaking structural reforms that would enhance economic efficiency and transparency. ${ }^{33}$ But then the November program did not work correctly, and the IMF met President Suharto to reverse the program's early gains. He urged the President not to ease interest rates prematurely, given intense pressure on the rupiah. In December, the President was sick and brought a new dimension to the crisis. This dimension was not only regarding the market but also the way presidential decisions were made. ${ }^{34}$

At the end of December, the economic condition in Indonesia had been worse than other East countries in the region. The currency of the rupiah was decreased below the standard of East Asian currencies and continuing to fall. "The collapse of the program, and especially the backtracking on individual reforms affecting vested interests close to the President, created the climate in which public attention focused on corruption and cronyism as defining characteristics of the economic system that evolved in Indonesia." 35

On January 15, 1998, the Indonesian authorities, through the Memorandum of Economic and Financial policies, announced a reinforcement and acceleration of the program to restraint the value of the rupiah. "Key reinforcing measures included:

a) Adjustments to the 1998/99 budget that would result in a public sector deficit of about 1 percent of GDP, to accommodate part of the impact on a budget of the economic slowdown;

b) The cancellation of 12 infrastructure projects and the revoking or discontinuation of privileges for the IPTN's airplane projects and the National Car project;

c) Further bank and corporate sector restructuring, including the subsequent announcement of a process to put in place a framework for creditors and debtors 
to deal on a voluntary, case-by-case basis with the external debt problems of Indonesian corporations; the establishment of the Indonesian Bank Restructuring Agency (IBRA); and a government guarantee on bank deposits and credits;

d) Limiting the monopoly of the national marketing board (BULOG) to rice, deregulating domestic trade in agricultural produce, and eliminating restrictive market arrangements; and

e) Measures to alleviate the suffering caused by the drought, including ensuring that adequate food supplies are available at reasonable prices." ${ }^{36}$

After the first memorandum, the economic situation was worsened. In addition, political issues such as revelations of corruption and nepotism, disclosure of military operations in Aceh, and the crime against humanity in Timor Leste had been the worst impact on economic development. Then in April 1998, the government issued a Supplementary Memorandum of Economic and Financial Policies, adapting the macroeconomic policies to the deteriorated economic situation and expanding the structural and banking reforms agreed in January.

This memorandum supported a robust monetary policy to ensure stabilization of the rupiah; to accelerated bank restructuring, with IBRA to continue its take-over or closure of weak or unviable institutions and be empowered to issue bonds to finance the restoration of financial viability to qualified institutions; the elimination of existing foreign ownership restrictions on banks; and the issuance of a new bankruptcy law; a comprehensive agenda of structural reforms to increase competition and efficiency in the economy, reinforcing the commitments made in January and including the further privatization of six major state enterprises and the identification of seven new enterprises for privatization in 1998/99; accelerate arrangements to develop a framework with foreign creditors to restore trade financing and to resolve the issues of corporate debt and interbank credit, with subsequent agreements on these issues reached on June 4,1998 after talks between Indonesian officials and international banks; strengthen the social safety net through support for small and medium-sized enterprises and through public works programs; and enhance the implementation and credibility of the program through daily monitoring by the Indonesian Executive Committee of the Resilience Council, in close cooperation with the IMF, the World Bank, and the ADB;

\footnotetext{
${ }^{36}$ Annual Report of the Executive Board, Financial Year 1998 (EPub), IMF, Washington, www.imf.org
} 
substantive actions prior to approval of the program by the IMF Executive Board, and frequent program reviews by the IMF Executive Board. ${ }^{37}$

The April program differed from the January program. This program had been changed in a significant monetary stance; the interest rates were raised sharply for the first time since the involvement of the IMF. Monetary control was regained, and BI limited the provision of liquidity support. ${ }^{38}$

The government issued a Second Supplementary Memorandum of Economic and Financial Policies on June 24, 1998, after the economic situation was worsened and the economic program-driven off track by social disturbances and political change in May. "The envisaged measures give high priority in strengthening the social safety net, comprehensively restructuring the banking system, and repairing the weakened distribution system, and include: to increase social expenditure to a level equivalent to 7.5 percent of GDP, with measures comprising, inter alia, the provision of food, fuel, medical, and other subsidies (which will be phased out after the economy has begun to improve); the expansion of employment-generating programs, supported by the World Bank, ADB and bilateral donors; and aid to students.

Also, to take measures to limit the budget deficit to 8.5 percent of GDP, a level that can be financed with foreign funds, including cuts in infrastructure projects and improvements in the efficiency of state-run operation. Then, to rehabilitate and strengthen the distribution system following the disruption caused by social disturbances. To ensure that there are adequate supplies of essential commodities, including establishing a particular monitoring unit to identify potential shortages of foodstuffs or distribution bottlenecks. Lastly, restructuring the banking system through measures to strengthen relatively sound banks partly through the infusion of new capital while moving swiftly to recapitalize, merge, or effectively close weak banks while maintaining the commitment to guarantee all depositors and creditors. A high-level Financial Sector Advisory Committee to advise on the coordination of actions for bank restructuring is being established; to establish an effective bankruptcy system, as an essential part of the corporate debt restructuring strategy envisaged by the June 4

\footnotetext{
${ }^{37}$ Ibid

${ }^{38}$ http://www.imf.org/external/np/ieo/2003/cac/pdf/Ind.pdf access date April 5, 2018
} 
agreement between the government and creditor banks on debt restructuring; and to strengthen the monitoring of the economic program". ${ }^{39}$

After Soeharto deposed in August 1998, President Habibie took over to negotiate a new program supported under the Extended Fund Facility (EFF). This program was designed for 26 months which EFF covered. "The authorities took decisive measures to deal with the banking sector problems and successfully secured relief for the corporate sector from foreign creditors and a rescheduling of external public sector debt through the Paris Club."40

In July 1998, the government issued a Letter of Intent and Memorandum of Economic and Financial Policies to request the cancellation of the current Stand-By Arrangement. The government requests a replacement with a new extended arrangement. The amount of credit available under the Extended Fund Facility (EFF) and its duration are identical to those remaining under the stand-by credit it would replace. Then it was followed by Letter of Intent and Supplementary Memorandum of Economic and Financial Policies on September 11, 1998, which dealt with aspects of the economic program developed further.

During Abdurrahman Wahid, known as Gusdur, presidency, there was a little bit of change. In this era, "the new government's most immediate challenge lies in regional unrest in East Timor, Ambon, Aceh, Irian Jaya, and other islands where internal migration patterns during the Suharto years created many latent tensions. However, Wahid's coalition will also come under other strains. That includes issues of politicized religious piety, ethnic and regional pressures such as the outright insurgent separatism of Aceh and Irian Jaya, irresponsible politics parties, and self-aggrandizement." ${ }^{41}$ Furthermore, the relation between Abdurrahman Wahid and the IMF was worsening. Wahid rejected some of the IMF's ideas, such as replacing the central bank governor; he did not want to deal with the IMF.

Gus Dur's political base does not lie in the moneyed interests that were so prominent in Soeharto's presidency. However, it is based in the traditionalist Muslim

\footnotetext{
${ }^{39}$ Annual Report of the Executive Board, Financial Year 1998 (EPub), IMF, Washington, www.imf.org ${ }^{40}$ The IMF and Recent Capital Account Crises: Indonesia, Korea, Brazil at http://www.ieoimf.org/ieo/files/completedevaluations/07282003main.pdf, access date at March 12, 2018

${ }^{41}$ Schlesinger Working Group on Strategic Surprises, Indonesia in Transition, Institute for the Study of Diplomacy, Georgetown University, page 2 at https://isd.georgetown.edu/sites/isd/files/SWG_1999_Fall_Indonesia_Transition.pdf access date, April 10,2018
} 
organization, the Nahdatul Ulama, with its network of religious schools and institutions, especially in East Java and in many other parts of the country. Gus Dur's way of thinking on money and politics can be characterized essentially based on mutual benefit, where many corrupt business people have made lots of money. Millions of poor kids in rural Java and elsewhere depend on the NU for their education - and indeed whole communities of desperately poor people who need help. Therefore, the money that the corrupt businessman had corrupted could be used to provide education for the poor people. Meanwhile, "the IMF and the press have been outraged in particular by the concessions that he has given to three heavily indebted businessmen (most prominently the head of the Texmaco group) who are representative of the corruption that has virtually bankrupted the Bank Indonesia." 42 Program review kept being postponed since the last LoI of September 2000. There was no loan disbursement until the change of government to President Megawati.

President Megawati started to deal with the IMF in the last few months of GusDur presidency, in her capacity as Vice President. "The issues and challenges facing President Megawati and her administration on their relationship with the IMF come mostly from the administrations before her. In this regard, discussing the current state of affairs of the working arrangement between the government and the IMF have to be viewed from the beginning of the IMF involvement in Indonesia's efforts to address the crisis through the stand-by arrangements (SBA)". ${ }^{43}$

"President Megawati took charge in resuming the talk with the IMF in June 2001, whereby some important decision was being made in fulfillment of some requirements that had to be done based on the latest agreement with the IMF. Those decisions had been followed with different steps that strengthened the relationship between the government and the IMF. The new LoI was signed on August 27, 2001, and the Board approved a new disbursement of USD 395 million. The election of Megawati to the presidency and the formation of the new Cabinet were very well accepted by the market such that rupiah was strengthened from around 11.000 to 8.500 to the USD 1 in August 2001". 44

\footnotetext{
${ }^{42}$ Gareth Evans, Indonesia: Closer to the Edge, at http://gevans.org/speeches/speech321.html access date April 6, 2018, at 01.00 am

${ }^{43}$ Lesley McCulloh, Disorder in Megawati's 'new' Indonesia, Boundary and Security Bulletin vol. 9 No. 3, p. 101-114, 2001.

${ }^{44}$ Ibid
} 
"Some thorny items of disagreement between President Wahid and the IMF on the necessary adjustments of 2001 budget, the amendment of central bank law, privatization, and sales of assets held by IBRA had been resolved which smoothen further the government relationship with the IMF. The latest one is the new budget of 2002, which the Parliament approved. However, the September 11 terror attack and its aftermath and the slowing down of the American and Japan and the European economy clouded the prospect of the economic recovery under the IMF-supported program. This development has been causing the excellent start of President Megawati's presidency to run out of steam. Uncertainty is returning, the rupiah is weakening, and economic recovery seems to go away at least for the time being." 45

During Susilo Bambang Yudhoyono's presidency from 2004 to 2014, the Indonesian economy grew at the fastest annual pace in six years last quarter. Gross domestic product increased 6.9 percent in the three months through December. ${ }^{46}$ The SBY and his Parliament learned from the previous President, where economic development depended on the IMF assistance. During his presidency, SBY started to pay the debt for the IMF for four years and will have completed its repaying of all debts, totaling $\$ 3.2$ billion, to the International Monetary Fund (IMF) within a week. ${ }^{47}$ From 1997 to 2003, Indonesia got a loan from the IMF of \$25 billion to rescue its failing banking system, rehabilitate its economy by restructuring private and government debt, and strengthen its foreign exchange reserves. "Much resentment arose, however, as the loan conditions required the government to implement some austerity measures under IMF supervision, including the privatization of state firms and the reduction of subsidies. Many nationalist-populist politicians and public figures saw these steps as harming the nation's interests. The government, under public pressure, eventually terminated its program with the IMF at the end of 2003, but remained under the IMF's "post-program monitoring" to assess the government's reform targets." 48

Besides reducing the state subsidies, he also announced other policies such as increasing the fuel prices, cash transfers to the poor, and distributing the education

\footnotetext{
${ }^{45}$ Ibid

${ }^{46}$ Shamim Adam and Widya Utami, Indonesia Economy Grows at fastes Pace in six year, at http://www.bloomberg.com/news/2011-02-07/indonesia-economy-expands-6-9-in-fourth-quarter-fastestpace-since-2004.html access date April 6, 2018, at 12.20 am

${ }^{47}$ Indonesia Finally its debt at http://uangkamihabis.blogspot.com/2010/04/indonesia-finally-pay-itsdebt-to-imf.html access date April, 6, 2018, at 12.40 am 
funding to schools in Indonesia. Even though the economic growth during his presidency was rapid, he faced Bank Century's problem, which had to pay 93 billion to solve it.

Through the central bank, SBY changed the policy to increase the interest rate so that the rupiah strengthen against the United States Dollar. In a statement announcing the rate decision, Bank Indonesia said it would keep a "close watch on future inflation developments and strengthen the rupiah exchange-rate policy in line with measures to curb future inflationary pressures." ${ }^{49}$ Besides, the SBY regimes provide legal certainty; therefore, the economic system grows fastest and does not relate to political issues. The latest news is that the IMF offered any assistance to Indonesia, but the Government of Indonesia does not plan to owe to the IMF. However, food and energy crises hoisted the middle haunt of world commodity prices. ${ }^{50}$

By developing the economy rapidly, the world perception of Indonesia has changed in the last five years. However, the government has to deal with problems like the macroeconomics outgrowth did not reach all residents, and most of them are still in poverty.

President Joko Widodo (also known as Jokowi) started his administration as a president on October 20, 2014. He will serve Indonesia until 2019 and can be reelected. During the first months of his administration, Jokowi was an embattled leader grappling with Indonesia's most severe political and religious tensions in two decades. Indonesia's economy was struggling to overcome weak demand for its natural resources, the rise of the Islamic State (ISIS) inspired radical Muslims worldwide, and annual forest fires demonstrated the challenge of forest protection. ${ }^{51}$ However, his popularity is near record highs. Against foes trying to exploit a blasphemy case against one of his allies, Jokowi has stamped his authority on the ruling coalition, Parliament, and the security forces. ${ }^{52}$ Therefore, the political policies of Jokowi did affect the

\footnotetext{
${ }^{49}$ Khalid Qayum, Indonesia's Rupiah, Bonds Advance After Policy Rate Increase, February 7, 2011 at http://www.bloomberg.com/news/2011-02-07/indonesia-s-rupiah-gains-after-central-bank-lifts-policyrate.html access date April 6, 2018, at $1.30 \mathrm{am}$

${ }^{50} \mathrm{http}: / / \mathrm{www}$. indo-stock.com/indonesia-does-not-plan-owes-to-imf.html access date April 6, 2018, at $1.50 \mathrm{am}$

${ }^{51}$ Visionary or Cautious Reformer? Indonesian President Joko Widodo's Two Years in Office, at http://time.com/4416354/indonesia-joko-jokowi-widodo-terrorism-lgbt-economy/ acces date April 2018.

52 Kanupriya Kapoor, John Chalmers, After Political Storm, Indonesia President Faces Economics Clouds, at https://www.reuters.com/article/us-indonesia-politics/after-political-storm-indonesia-presidentfaces-economic-clouds-idUSKCN1BF07S acces date April 8, 2018
} 
economic growth, particularly when it comes to how the policies could bring economic better.

His priority is to build up the infrastructure, for example, highways, airports, and housing. On the macro side, the economic development was slow, from a $6,3 \%$ decline to $5,5 \%$ in his first year of administration. However, now it reaches the positive value, particularly the level of economic growth, poverty, unemployment, and discrepancy of the poorest and wealthy. ${ }^{53}$ In addition, Jokowi is also known as a phenomenal decisionmaker, like withdraw the state subsidy for gasoline and increase the power tariff for the wealthy people. ${ }^{54}$

Jokowi established an Economic Creative Body (Bekraf) to accelerate the economic outgrowth. The head of the Bekraf, Triawan Munaf, said that the development of the economy would not depend on crude natural resources in the future. The data show that economic creativity contributed $7,38 \%$ of the national economy with GNP IDR 852,24 trillion. ${ }^{55}$ Triawan also mentioned some obstacles in developing economic creativity; first, business and investment environment, particularly the infrastructure supporting the businessman and society. Second, some of economics' sector creative is still on the negative investment list, especially in foreign investment. Otherwise, the investment will support less infrastructure and technology. ${ }^{56}$

\section{Conclusion}

The IMF is one of the institutions which provides financial assistance to countries that face financial crises. Naturally, the IMF was designed to monitor and help adjustable exchange rates globally, considering the currencies of different countries are convertible into gold. The central goals of structural adjustment are to open up countries to have transnational corporations access their workers and natural resources, shrink the size and role of government, rely on market forces to distribute resources and services, and integrate emerging countries into the global economy.

\footnotetext{
${ }^{53}$ Zulfi Suhendra, Headline: Terobosan Ekonomi 3 Tahun Jokowi - JK, at https://www.liputan6.com/bisnis/read/3133029/headline-terobosan-ekonomi-3-tahun-jokowi-jk access date April 8, 2018

${ }^{54}$ Ibid

55 Tiga Tahun Pemerintahan Jokowi - JK bidang Perekonomian : Pondasi Ekonomi Bagus jadi Modal Dasar at http://ksp.go.id/tiga-tahun-pemerintahan-jokowi-jk-bidang-perekonomian-pondasi-ekonomibagus-jadi-modal-dasar/index.html access date April 8, 2018.

${ }^{56}$ Ibid
} 
By involving in decision making, particularly in economics, a country will be under the IMF surveillance, and mostly the policies must be adjusting as the IMF said. On one side, the interference of the IMF will bring better financial, especially if the policies are in the right place. On the other hand, a country will reject the financial aid from the IMF because the IMF will require the country to open its economy to foreigners. The successful aid in Europe could not be the same applying in Asia.

\section{BIBLIOGRAPHY}

\section{a. Books and Journals}

Avramovic, Dragoslav,1983, IMF Conditionality: The Role of The International Monetary Fund: Dispute, Qualifications, and Future, edited by John Williamson, Institute for International Economics, Washington DC.

Fischer Stanley, IMF Essays from a Time of Crisis: The International Financial System, Stabilization and Development, the MIT Press, Cambridge, Massachusetts, London, England, 2004.

Lesley McCulloh, Disorder in Megawati's 'new' Indonesia, Boundary, and Security Bulletin vol. 9 No. 3.

Guitian, Manuel, Conditionality: Access to Fund Resources, "Finance and Development," 1981.

Schlesinger Working Group on Strategic Surprises, Indonesia in Transition, Institute for the Study of Diplomacy, Georgetown University

Wang Jiangyu, 2011, Lecture material : International Financial Regulation, Part II: IMF, Financial Liberalization, and Financial Crises

Vreeland, James Raymond, the International Monetary Fund, Routledge Global Institutions, New York, 2006

\section{b. Internet}

Annual Report of the Executive Board, Financial Year 1998 (EPub), IMF, Washington, www.imf.org https://isd.georgetown.edu/sites/isd/files/SWG_1999_Fall_Indonesia_Transition. pdf

Gareth Evans, Indonesia: Closer to the Edge, at http://gevans.org/speeches/speech321.html

Indonesia Finally its debt at http://uangkamihabis.blogspot.com/2010/04/indonesia-finally-pay-its-debt-toimf.html 
Kanupriya Kapoor, John Chalmers, After Political Storm, Indonesia President Faces Economics Clouds, at https://www.reuters.com/article/us-indonesiapolitics/after-political-storm-indonesia-president-faces-economic-cloudsidUSKCN1BF07S

Khalid Qayum, Indonesia's Rupiah, Bonds Advance After Policy Rate Increase, February 7, 2011, at http://www.bloomberg.com/news/2011-02-07/indonesia-srupiah-gains-after-central-bank-lifts-policy-rate.html

Martin Feldstein, Refocusing the IMF, originally Published in Foreign Affairs, in http://www.nber.org/feldstein/fa0398.html

Presentation by Stanley Fischer to the International Financial Institution Advisory

Commission, $\quad$ February 2000 at
https://www.imf.org/en/News/Articles/2015/09/28/04/53/sp020200

Recovery from the Asian Crisis and the Role of the IMF at Saxena, Sweta Chaman, A country Report on Indonesia, May 8, 1998 at http://citeseerx.ist.psu.edu/viewdoc/download;jsessionid=383453C0F3A495529 3762F3070F96E62?doi=10.1.1.456.8567\&rep=rep1\&type=pdf

Shamim Adam and Widya Utami, Indonesia Economy Grows at the fastest pace in six years, at http://www.bloomberg.com/news/2011-02-07/indonesia-economyexpands-6-9-in-fourth-quarter-fastest-pace-since-2004.html

Tiga Tahun Pemerintahan Jokowi - JK bidang Perekonomian : Pondasi Ekonomi Bagus jadi Modal Dasar at http://ksp.go.id/tiga-tahun-pemerintahan-jokowi-jk-bidangperekonomian-pondasi-ekonomi-bagus-jadi-modal-dasar/index.html

The IMF and Recent Capital Account Crises: Indonesia, Korea, Brazil at http://www.ieo-imf.org/ieo/files/completedevaluations/07282003main.pdf

Visionary or Cautious Reformer? Indonesian President Joko Widodo's Two Years in Office, at http://time.com/4416354/indonesia-joko-jokowi-widodo-terrorismlgbt-economy/

Van de Gevel, Diagnosis of Financial Crisis in Asia, Tilburg University, at https://pure.uvt.nl/portal/en/publications/diagnosis-of-financial-crisis-inasia(04e31e54-c9bc-49c0-a2f4-bafa9971f0c2).html

Zulfi Suhendra, Headline: Terobosan Ekonomi 3 Tahun Jokowi - JK, at https://www.liputan6.com/bisnis/read/3133029/headline-terobosan-ekonomi-3tahun-jokowi-jk 